\title{
PENGENALAN TEKNOLOGI NAVIGASI BIDANG MARITIM MELALUI VIRTUAL OUTING UNTUK ANAK-ANAK JOGJAKARTA MONTESSORI SCHOOL
}

\author{
Benny Hartanto1), Ningrum Astriawati2), Waris Wibowo'2), Didik Sisdiyanto') \\ 1)Prodi Studi: Studi Nautika, Sekolah Tinggi Maritim Yogyakarta, DIY, Indonesia \\ 2) Prodi Studi Permesinan Kapal, Sekolah Tinggi Maritim Yogyakarta, DIY, Indonesia \\ Corresponding author : Ningrum Astriawati \\ E-mail : astriamath@il.com
}

Diterima 29 Oktober 2021, Disetujui 17 November 2021

\begin{abstract}
ABSTRAK
Pengabdian masyarakat ini bertujuan untuk mengenalkan dan mensosialisasikan inovasi teknologi navigasi dalam bidang maritim melalui virtual outing untuk anak-anak Jogjakarta Montessori School Elementary Program. Peserta yang dilibatkan dalam kegiatan pengabdian ini yaitu Guru-guru SD dan anak-anak kelas 4,5 dan 6. Rangkaian kegiatan ini meliputi 3 tahapan yaitu: Tahap persiapan, tahap pelaksanaaan dan tahap evaluasi. Tahap persiapan meliputi persiapan alat-alat navigasi yang dimiliki oleh Sekolah Tinggi Maritim Yogyakarta dan pembuatan materi. Tahap pelaksanaan meliputi pembukaan, pemaparan materi dan penjelasan alat-alat navigasi di laboratorium simulator, kemudian dilanjutkan dengan diskusi dan tanya jawab peserta yang hadir. Pada tahap evaluasi, peserta mengisi kuesioner melalui google form, hasil kuesioner yaitu meliputi: aspek presentasi yang disampaikan pemateri memiliki nilai kepuasan sebesar $76.27 \%$, aspek atensi yang disampaikan oleh pemateri terhadap pengenalan alat-alat navigasi mempunyai nilai kepuasan sebesar $83.05 \%$, aspek motivasi tanya jawab mempunyai nilai kepuasan sebesar $88.14 \%$, rata-rata semua aspek mempunyai nilai kepuasan sebesar $82.48 \%$
\end{abstract}

Kata kunci: teknologi; navigasi; maritim; virtual outing.

\begin{abstract}
This community service aims to introduce and socialize navigation technology innovations in the maritime field through virtual outings for the children of the Elementary Program in the Yogyakarta Montessori School. The participants involved in this service activity are elementary school teachers and children class 4,5 and 6 . This series of activities includes 3 stages, namely: the preparation stage, the implementation stage and the evaluation stage. The preparation stage completes the preparation of navigation tools owned by the Sekolah Tinggi Maritim Yogyakarta and the manufacture of materials. The implementation stage of the opening, the presentation of the material and navigational tools was followed by discussion and question and answer from the participants present. At the evaluation stage, participants filled out a questionnaire through the google form, the results of the questionnaire include: aspects of the presentation delivered by the speaker have a satisfaction value of $76.27 \%$, aspects of attention submitted by speakers to the introduction of navigation tools have a satisfaction value of $83.05 \%$, aspects of question and answer motivation have a satisfaction value of $88.14 \%$, on average all aspects have a satisfaction value of $82.48 \%$.
\end{abstract}

Keywords: technology; navigation; maritime; virtual outing

\section{PENDAHULUAN}

Dalam dunia navigasi pelayaran, peran komputer dan sistem komunikasi sangat penting sekali. Kemajuan teknologi di bidang Informatika dan Telekomunikasi abad ini salah satunya ditandai dengan ditemukannya fungsi multi prosesor yang sangat cepat, dan kapasitas penyimpanan yang sangat besar serta bentuknya yang semakin kecil(Nuryanto, 2012). Dengan adanya teknologi tersebut, maka sistem yang sangat kompleks dapat diringkas dalam suatu sistem komputer yang terintegrasi padu. Untuk memperluas jangkauan keterbatasan indra manusia, banyak orang yang telah memanfaatkan bantuan sistem identifikasi otomatis pada kapal dan satelit yang terpadu (ARINDA, 2020). Dengan menggunakan sistem GPS (Global Positioning System) navigator dapat dengan mudah mengetahui letak posisi kapal (Purnama, 2011). Dengan alat bantu AIS (Automatic Identification System) navigator juga bisa memantau keberadaan kapal lain di sekitar kapalnya (Masmilah et al., 2019). Pelayaran pada malam hari menjadi semakin mudah dilakukan dengan adanya sistem Radar (Radio Detection and 
Ranging), yang dapat memantau keberadaan lingkungan sekitar kapal dalam radius tertentu (Lorenz et al., 2001).

Sebuah sistem navigasi dapat di desain dan kontruksi untuk menunjang perencanaan pelayaran yang lebih aman dengan dukungan teknologi yang telah ada. ECDIS (Electronic Chart Display and Information System) merupakan suatu terobosan teknologi sebagai alat bantu navigasi elektronik yang cerdas(Gouic, 1998). Dengan adanya ECDIS maka pelayaran dapat dilakukan dengan lebih mudah, tanpa mengesampingkan keselamatan dan keamanan perjalanan di laut. ECDIS bertugas menerjemahkan semua sensor yang diintegrasikan pada sistem aplikasi, antara lain sensor AIS, radar, kompas, serta GPS (Kazimierski \& Stateczny, 2013). Peta yang terintegrasi juga semakin memudahkan navigator mengetahui keberadaan kapal-kapal lain di laut dan di pantai. Selain itu, peta yang terintegrasi pada ECDIS tidak hanya menyimpan informasi bentuk pantai, tetapi juga terdapat informasi kedalaman perairan, posisi obyek-obyek sekitar pantai, serta area berbahaya lain di laut. Selain berfungsi memetakan wilayah perairan, ECDIS juga dapat digunakan untuk melakukan perencanaan rute pelayaran, sehingga ECDIS berfungsi juga untuk meningkatkan level keamanan sebuah rute pelayaran.

Selama ECDIS diaktifkan, maka segala event maupun kondisi tak normal yang terjadi di sepanjang pelayaran akan tetap tercatat dan dikirim ke sebuah sistem Alarm. Demikian pula yang terjadi dengan setiap data teknis yang terkait dengan keamanan pelayaran. Fungsi lain dari Alarm adalah sebagai peringatan dini tentang suatu bahaya yang mungkin akan terjadi. Diharapkan, lewat mekanisme alarm ini segala tindakan pencegahan yang perlu dilakukan dapat segera diatasi sebelum bahaya yang sesungguhnya benar-benar terjadi. Informasi yang dikirim dari sistem Alarm ini kemudian akan disimpan hingga batas periode yang ditentukan dalam fungsi Blackbox berdasarkan klasifikasinya. Report informasi datanya dapat segera dicetak melalui printer.

Pengenalan teknologi navigasi dalam bidang kemaritiman merupakan hal yang menarik dan penting untuk diketahui dan dimengerti oleh siapa saja yang tertarik dengan profesi seorang Pelaut (Seaferer). Pengenalan teknologi navigasi dalam bidang kemaritiman melalui video-video seperti apikasi videoscribe dalam bidang kemaritiman juga dapat memotivasi hasil belajar untuk para pelajar (Astriawati, 2020). Bagi generasi muda yang tertarik dengan petualangan dan tantangan menaklukkan samodera dengan menaiki dan mengendalikan kapal melintasi samodera luas di berbagai belahan benua. Untuk mewujudkannya tentu tidak hanya bermodal berani dan nekad saja melainkan harus dibekali ilmu yang cukup dan beberapa kompetensi serta ketrampilan yang mendukung kearah keselamatan, keamanan dan kenyamanan pelayaran. Oleh karena itu perlu kiranya untuk memperkenalkan teknologi navigasi kepada anak bangsa sebagai generasi penerus nenek moyangku seorang Pelaut yang tangguh dan handal. Kelemahan dibidang navigasi akan memperburuk nasib Pelaut dikancah dunia dan yang meratifikasi regulasi maupun menerapkannya dengan penguasaan ilmu dan ketrampilan dalam bernavigasi merekalah yang akan menaklukkan ganasnya samodera luas.

Membuka wawasan pikiran generasi muda Melenial tentu harus menggunakan metode visual yang lebih menarik dibandingkan dengan narasi dan diskriptif. Mengenalkan beberapa alat-alat navigasi baik konvensional maupun elektronik dengan mengemasnya dalam bingkaian folder yang menarik untuk dinikmati dan pengalaman kisah heroik sang Pelaut itu sendiri menambah daya tarik yang bisa menghipnotis kawula muda apalagi dikalangan anak-anak.

Oleh karena itu pengenalan teknologi navigasi dan seluk beluknya secara virtual disertai dengan cerita dan pengalaman dari Pelaut sendiri menjadi kunci ketertarikan dan animo kalangan Milenial terhadap profesi Pelaut (Seaferer) dan Kemaritiman. Dari beberapa alasan tersebut maka Sekolah Tinggi Maritim Yogyakarta mengadakan pengabdian kepada masyarakat mengenai pengenalan teknologi navigasi bidang maritim melalui virtual outing untuk anak-anak Jogjakarta Montessori School.

\section{METODE}

Pelaksanaan kegiatan pengabdian masyarakat ini bertujuan untuk mengenalkan dan mensosialisasikan inovasi teknologi navigasi dalam bidang maritim melalui virtual outing untuk anak-anak Jogjakarta Montessori School Elementary Program. Kegiatan pengabdian masyarakat ini diselenggarakan pada hari Kamis, 26 Agustus 2021. Peserta yang dilibatkan dalam kegiatan pengabdian ini yaitu Guru-guru SD dan anak-anak kelas 4,5 dan 6. Jumlah peserta dalam kegiatan ini berjumlah 59 orang yang terdiri dari 6 orang guru dan 53 anak-anak Sekolah Dasar kelas 4, 5 dan 6 . Rangkaian kegiatan ini meliputi 3 tahapan yaitu: Tahap persiapan, tahap pelaksanaaan dan tahap evaluasi. Tahap persiapan meliputi persiapan alat-alat navigasi yang dimiliki oleh Sekolah Tinggi Maritim 
Yogyakarta dan pembuatan materi. Tahap pelaksanaan meliputi pembukaan, pemaparan materi dan penjelasan alat-alat navigasi di laboratorium simulator, kemudian dilanjutkan dengan diskusi dan tanya jawab peserta yang hadir. Pada tahap evaluasi, peserta mengisi kuesioner kepuasan melalui google form. Pengabdian ini dikatakan berhasil apabila ratarata seluruh aspek kepuasan mencapai $80 \%$.

\section{HASIL DAN PEMBAHASAN Tahap Persiapan}

Tahap awal pelaksanaan kegiatan ini yaitu persiapan alat-alat navigasi yang dimiliki oleh Sekolah Tinggi Maritim Yogyakarta di Laboratorium Simulator dan pembuatan materi presentasi yang akan dipresentasikan waktu pelaksanaan Pengabdian. Selain itu juga menyiapkan materi pengabdian dan zoom meeting untuk pelaksanaan virtual outing.

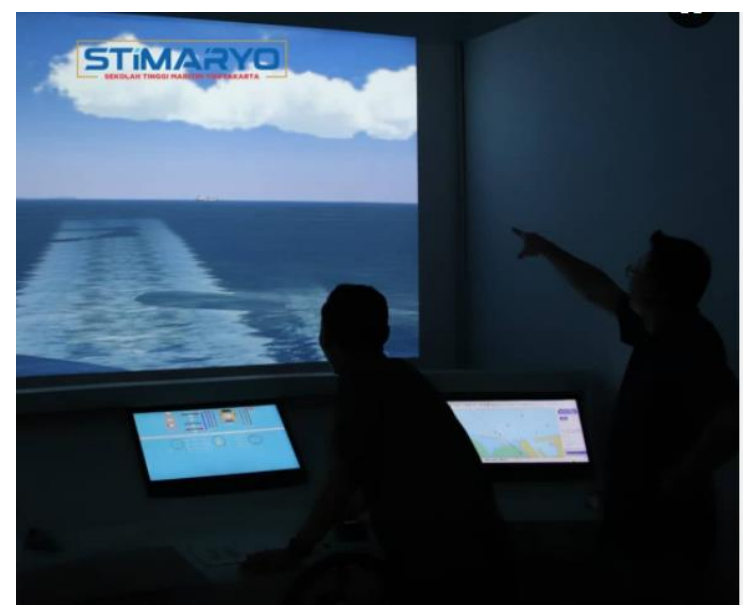

Gambar 1. Proses persiapan pengabdian oleh tim pengabdi di Laboratorium Simulator

\section{Tahap Pelaksanaan}

Rangkaian pada kegiatan ini meliputi pembukaan, pemaparan materi dan pengenalan alat-alat navigasi dilanjutkan dengan diskusi dan tanya jawab peserta yang hadir. Pada sesi pembukaan dihadiri oleh tim pengabdi dari Sekolah Tinggi Maritim Yogyakarta dan dilanjutkan dengan pemaparan materi melalu presentasi. Materi yang diberikan meliputi: Polynesian Explorer, Teknik-teknik navigasi Navigasi Polinesia, Sistem Analog dan Digital, Sistem Identifikasi Otomatis atau Automatic Identification System (AIS), Global Positioning System, Global Positioning System, pentingnya radar sebagai alat navigasi dan deteksi dan kompas pada system navigasi.

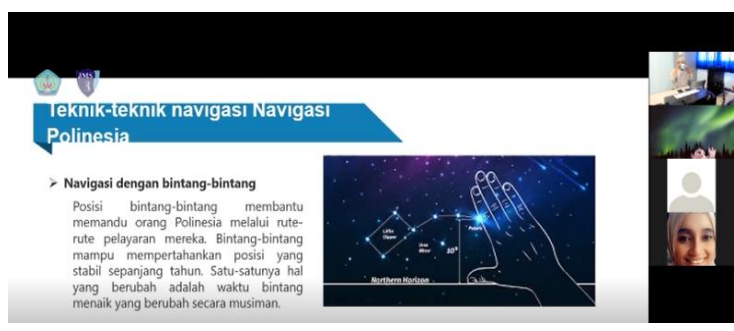

Gambar 2. Pemaparan materi secara virtual melalui zoom meeting oleh tim pengabdi

Pada tahap pelaksanaan ini dilanjutkan dengan sesi penjelasan alat-alat navigasi secara virtual di laboratorium simulator. Tim pengabdi menjelaskan terkait dengan fungsi dan kegunaan alat-alat yang berada di laboratorium simulator. Diantaranya penjelasan mengenai NET simulator, Radar Arpa Simulator, Bridge Simulator, GMDSS (Global Maritime Distress and Safety System) simulator.

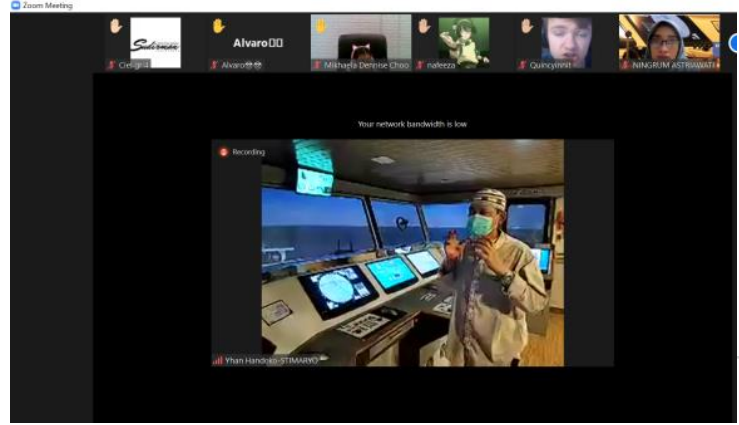

Gambar 3. Penjelasan secara virtual alat-alat navigasi

Sesi selanjutnya diisi dengan tanya jawab oleh peserta pengabdian. Sesi tanya jawab berlangsung sangat seru karena kebanyakan peserta dari anak-anak Sekolah Dasar yang ingin mengetahui terkait alat-alat navigasi diatas kapal.

\section{Tahap evaluasi}

Tahapan selanjutnya yaitu tahap evaluasi, pada tahap ini dilakukan pengisian kuisioner melalui google form oleh para peserta pengabdian, sebagai bahan evaluasi kegiatan yang sudah dilaksanakan. Kemudian dilanjutkan photo bersama secara virtual. 


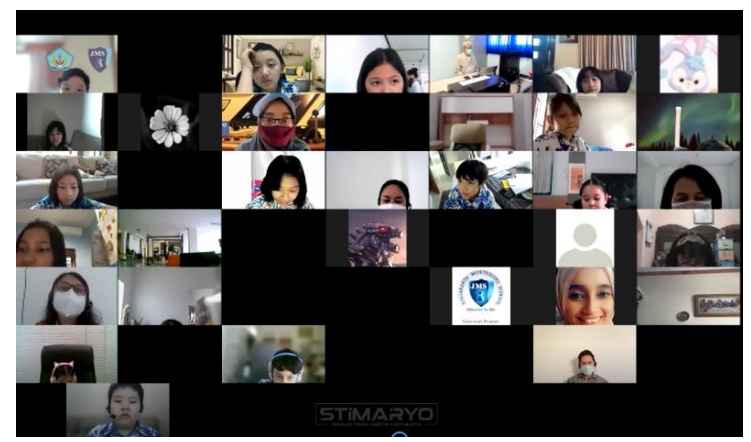

Gambar 4. Photo bersama peserta pelatihan dan tim pengabdi

Kuesioner kepuasan terhadap peserta terdiri dari 3 aspek yang meliputi: aspek presentasi yang disampaikan pemateri, aspek atensi yang disampaikan oleh pemateri terhadap pengenalan alat-alat, dan aspek motivasi tanya jawab antara tim pengabdi dan peserta pengabdian. Dari hasil kuesioner diperoleh seperti gambar dibawah ini.

\section{Hasil Kuesioner Pengabdian}

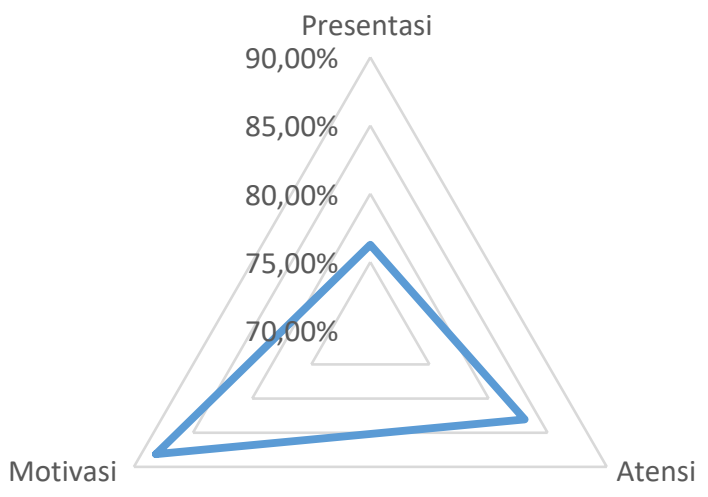

Gambar 5. Hasil kuesioner

Adapun hasil kuesioner dari peserta pengabdian masyarakat adalah sebagai berikut: aspek presentasi yang disampaikan pemateri memiliki nilai kepuasan sebesar $76.27 \%$, aspek atensi yang disampaikan oleh pemateri terhadap pengenalan alat-alat navigasi mempunyai nilai kepuasan sebesar 83.05\%, aspek motivasi tanya jawab mempunyai nilai kepuasan sebesar $88.14 \%$, rata-rata semua aspek mempunyai nilai kepuasan sebesar $82.48 \%$. Sehingga pengabdian masyarakat ini dikatakan berhasil.

\section{SIMPULAN DAN SARAN SIMPULAN}

Kegiatan pengabdian masyarakat ini berjalan dengan lancar. Tahapan pengabdian yang terdiri dari tahap persiapan, tahap pelaksanaaan dan tahap evaluasi. Tahap persiapan meliputi persiapan alat-alat navigasi yang dimiliki oleh Sekolah Tinggi Maritim Yogyakarta dan pembuatan materi. Tahap pelaksanaan meliputi pembukaan, pemaparan materi dan penjelasan alat-alat navigasi di laboratorium simulator, kemudian dilanjutkan dengan diskusi dan tanya jawab peserta yang hadir. Pada tahap evaluasi, peserta mengisi kuesioner melalui google form. Semua tahapan dilewati dengan lancer. Peserta pelatihan sangat antusias dalam kegiatan, itu dibuktikan dengan hasil kuisioner dengan rata-rata kepuasan sebesar $82.48 \%$ dari semua aspek.

\section{SARAN}

Pengabdian sejenis ini perlu ditingkatkan di lingkungan Sekolah Tinggi Maritim Yogyakarta, hal ini mempunyai tujuan untuk mengenalkan ke masyarakat luas terkait alat-alat navigasi kapal secara real time sehingga memiliki peluang untuk meningkatkan animo masyarakat terhadap ilmu-ilmu di bidang kemaritiman.

\section{UCAPAN TERIMAKASIH}

Terimakasih yang sebesar-besarnya kepada Managemen dan Lembaga Penelitian dan Pengabdian kepada Masyarakat Sekolah Tinggi Maritim Yogyakarta yang telah mendanai pengabdian ini secara penuh.

\section{DAFTAR RUJUKAN}

ARINDA, M. S. (2020). ANALISIS FAKTORFAKTOR YANG MEMPENGARUHI KESELAMATAN PELAYARAN KAPAL PENUMPANG DIPELABUHAN TANJUNG EMAS SEMARANG (Studi di KM. Kelimutu PT. Pelni Cabang Semarang). SKRIPSI.

Astriawati, N. (2020). Development of interactive media based on videoscribe with realistic mathematics education approach to navigation. Math Didactic: Jurnal Pendidikan Matematika, 6(3), 321333.

Gouic, M. Le. (1998). ECDIS: Electronic Chart Display and Information System. Navigation-Paris, 46(181), 39-51.

Kazimierski, W., \& Stateczny, A. (2013). Fusion of Data from AIS and Tracking Radar for the Needs of ECDIS. 2013 Signal Processing Symposium (SPS), 1-6.

Lorenz, R. D., Elachi, C., West, R. D., Johnson, W. T. K., Janssen, M. A., Moghaddam, M., Hamilton, G. A., Liepack, O., Bunker, A., \& Roth, L. E. (2001). Cassini radio detection and ranging (RADAR): Earth and venus observations. Journal of Geophysical Research: Space Physics, 106(A12), 30271-30279.

Masmilah, M., Setiawan, H., Hermawansyah, W., \& Haryadi, R. (2019). Rancang 
Bangun Sistem Monitoring Kapal Menggunakan Data Automatic Identification System (AIS) Dengan Geographic Information System (GIS). Prosiding TAU SNAR-TEK Seminar Nasional Rekayasa Dan Teknologi, 1(1), 24-29.

Nuryanto, H. (2012). Sejarah perkembangan teknologi informasi dan komunikasi. PT Balai Pustaka (Persero).

Purnama, B. E. (2011). Pemanfaatan Global Positioning System Untuk Pelacakan Objek Bergerak. Speed-Sentra Penelitian Engineering Dan Edukasi, 1(4). 